\title{
LITERATUR REVIEW: TINGKAT KECEMASAN DAN KEPATUHAN KUNJUNGAN BALITA KE POSYANDU DI MASA PANDEMI COVID-19
}

\author{
A Literature Review: Level Anxiety and Compliance of Toddler Visits to Posyandu During The \\ Covid-19 Pandemic
}

\author{
Rara Roro Retno Ayu Ericha $\mathrm{K}^{1}$, Eka Sulastri Ningsih ${ }^{2}$, \\ Rizkyah Wulan Septyaningrum ${ }^{3}$, Chintya Ayu Lestari ${ }^{4}$, Sherly Nur Fitri Jannah ${ }^{5}$
}

${ }^{1}$ Sarjana Kebidanan Sekolah Tinggi Ilmu Kesehatan Pemkab Jombang

\section{Riwayat artikel}

Diajukan: Agustus 2021

Diterima: September 2021.

\section{PenulisKorespondensi:}

- Rara Roro Retno Ayu Ericha K

- Sarjana Kebidanan Sekolah Tinggi Ilmu

Kesehatan Pemkab Jombang

- r.roro.retno.ayu@gma il.com

\section{Kata Kunci:}

Kecemasan, balita, Posyandu, Covid-19.

\section{Abstrak}

Posyandu atau Pos Pelayanan Terpadu adalah suatu bentuk keterpaduan pelayanan kesehatan yang dilaksanakan di suatu wilayah kerja puskesmas, dimana pelaksanaannya di setiap kelurahan oleh bidan desa beserta anggotanya yaitu anggota kader dan PKK. Namun, akhir-akhir ini beberapa kegiatan Posyandu terpaksa harus dihentikan agar meminimalisir penyebaran Covid-19. Selama masa pandemi orangtua merasa cemas saat akan membawa anaknya ke Posyandu, yang mana hal ini berarti kunjungan balita ke Posyandu menjadi berkurang. Tujuan dari literature review adalah untuk review tingkat kecemasan dan kepatuhan kunjungan balita ke Posyandu di masa pandemi. Literature review dilakukan berdasarkan issue, metodologi, persamaan dan proposal penelitian lanjutan. Dari 6 penelitian yang digunakan 3 diantaranya menggunakan metode penelitiaan deskriptif dan 3 yang lain menggunakan metode kualitatif. Populasinya adalah seluruh ibu yang memiliki bayi-balita dan sampel yang diguanakan adalah sebagian ibu yang memilki bayi-balita, kader Posyandu, serta bidan desa. Dari 6 penelitian didapatkan bahwa kecemasan yang dialami orangtua terhadap Covid-19 memiliki banyak faktor penyebab, dimana kecemasan tersebut akan mempengaruhi tingkat kepatuhan kujungan balita ke Posyandu. Tingkat kecemasan dan kepatuhan kunjungan balita ke Posyandu merupakan sebuah masalah yang harus dikaji dan dicarikan jalan keluar sehingga diharapkan semua bayi-balita tetap melakukan kunjungan Posyandu di masa pandemi.

\section{Abstract}

Posyandu or Integrated Service Post is a form of integrated health service carried out in a puskesmas working area, where it is implemented in every village by the midwife and the members, namely cadres and PKK. However, recently some Posyandu activities had to be stopped in order to minimize the spread of Covid-19. During the pandemic, parents feel anxious when they take their children to Posyandu, which means that toddlers' visits to Posyandu are reduced. The purpose of the literature review is to review the level of anxiety and compliance of toddlers' visits to Posyandu during the pandemic. Literature review is carried out based on issues, methodologies, 
similarities and further research proposals. Of the 6 studies used, 3 of them used descriptive research methods and 3 others used qualitative methods. The population is all mothers who have infants and toddlers and the samples used are some mothers who have infants, Posyandu cadres, and midwife. From 6 studies, it was found that the anxiety experienced by parents about Covid-19 has many factors, where this anxiety will affect the level of adherence to visits by toddlers to the Posyandu. Discussion: The level of anxiety and compliance of toddlers' visits to the Posyandu is a problem that must be studied and found a way out so that it is hoped that all infants and toddlers will continue to visit Posyandu during the pandemic. 


\section{Pendahuluan}

Posyandu atau Pos Pelayanan

Terpadu adalah suatu bentuk keterpaduan pelayanan kesehatan yang dilaksanakan di suatu wilayah kerja puskesmas, dimana pelaksanaannya di setiap kelurahan oleh bidan desa beserta anggotanya yaitu anggota kader dan PKK. Dengan demikian Posyandu merupakan kegiatan kesehatan dasar yang diselenggarakan oleh masyarakat dan untuk masyarakat yang dibantu oleh petugas kesehatan (Cessnasari, 2005). Posyandu merupakan wadah titik temu antara pelayanan profesional dari petugas kesehatan serta peran masyarakat dalam menanggulangi masalah kesehatan masyarakat, terutama dalam penurunan angka kematian bayi dan angka kelahiran. Pelayanan kesehatan yang dilaksanakan di Posyandu beruapa Kesehatan Ibu dan Anak (KIA), Keluarga Berencana (KB), Imunisasi dan Penanggulangan Diare dan Gizi (Nadia S dan Rury F, 2021). Posyandu merupakan salah satu bentuk Upaya Kesehatan Bersumberdaya Masyarakat (UKBM) yang dilaksanakan oleh, dari, dan bersama masyarakat, untuk memberdayakan dan memberikan kemudahan kepada masyarakat guna memperoleh pelayanan kesehatan bagi ibu, bayi dan anak balita. Upaya peningkatan peran dan fungsi Posyandu bukan semata-mata tanggungjawab pemerintah saja, namun semua komponen yang ada di masyarakat, termasuk kader (Kemenkes RI, 2012). Posyandu sudah dikenal sejak lama sebagai pusat pelayanan dasar bagi ibu hamil, orang tua dan balita. Kini Posyandu dituntut untuk mampu menyediakan informasi kesehatan secara lengkap sehingga menjadi sentra kegiatan kesehatan masyarakat. Dengan demikian tujuan didirikannya Posyandu adalah untuk menurunkan
Angka Kematian Bayi (AKB) dan anak balita, agar terwujud keluarga kecil bahagia sejahtera (Anggi F, dkk, 2020).

Namun, akhir-akhir ini beberapa kegiatan Posyandu terpaksa harus dihentikan agar meminimalisir penyebaran Covid-19. (Anggi F, dkk, 2020). Corona Virus Disease-19 (Covid-19) merupakan suatu penyakit menular yang disebabkan oleh Virus Corona (Virus SARSCOV 2) dan menyerang dunia (Zhong et al, 2020). Infeksi yang disebabkan oleh Covid-19 bisa menyebabkan infeksi pernapasan ringan sampai sedang, seperti flu atau infeksi sistem pernapasan dan paruparu, seperti pneumonia. Sementara itu, Indonesia merupakan negara yang melaporkan adanya kasus Covid-19 yang terus bertambah secara fluktuatif di wilayah Indonesia (Purnamasari dan Raharyani, 2020). Covid-19 telah dinyatakan sebagai pandemi dunia oleh World Health Organization (WHO). Bukan hanya WHO, pemerintah Indonesia juga menetapkan Covid-19 sebagai pandemi, pemerintah juga telah melakukan berbagai upaya-upaya dalam pencegahan penyebaran Covid-19 yang meliputi pembatasan keramaian, perjalanan, adanya isolasi mandiri serta penutupan fasilitas hingga pengaturan pelayanan publik. Dilaporkan kondisi tersebut juga berpengaruh terhadap pelayanan posyandu diantaranya pengukuran tumbuh kembang dan imunisasi (Direktur Jenderal Pencegahan dan Pengendalian Penyakit Kemenkes RI, 2020).

Sementara kegiatan Posyandu dilakukan setiap pertengahan bulan sekali dalam satu bulan yang kegiatannya dilakukannya di balai desa. Tingkat partisipasi masyarakat dalam keikutsertaan kegiatan Posyandu tentu berbeda apabila 
dibandingkan dengan sebelum adanya pandemi Covid-19. Pada masa pandemi saat ini, masyarakat cenderung cemas membawa anaknya ke Posyandu, hal ini diakibatkan adanya rasa takut sang anak akan tertular Covid-19. Berdasarkan Keputusan Menteri Kesehatan Nomor 1529 tahun 2010 tentang Pedoman Umum Pengembangan Desan dan Keluarga Siaga Aktif bahwa keaktifan Posyandu merupakan salah satu kriteria untuk mencapai desa dan kelurahan yang siaga aktif. Berdasarkan fakta yang ada, kondisi sosial masyarakat selama pandemi Covid- 19 ini cukup berpengaruh terhadap pelayanan kesehatan bayi dan balita di Posyandu, termasuk pelayanan imunisasi di tengah pandemi Covid-19 cenderung terabaikan, sebab seluruh konsentrasi pelayanan dan kesehatan tertuju pada kasus Covid-19. Selain itu, kurangnya kesadaran masyarakat untuk membawa balita ke Posyandu juga menjadi faktor penyebab menurunnya jumlah balita yang mendapatkan imunisasi serta pelayanan di Posyandu selama masa pandemi ini. Pemberian imunisasi, penyimpangan dalam mengasuh bayi dan pemantauan pada perkembangan bayi tidak kalah pentingnya dengan pencegahan Covid-19 (Nadia S dan Rury F, 2021). Hal ini dikarenakan imunisasi dan pelayanan kesehatan bayi serta balita terutama pada fase awal dapat mempengaruhi tumbuh kembang anak dan meningkatkan daya tahan tubuh anak (Nadia S dan Rury F, 2021)

Apabila keadaan tersebut terus terjadi maka akan mengakibatkan cakupan imunisasi nasional mengalami penurunan, dan masalah gizi anak akan meningkat baik itu gizi buruk ataupun stunting. Di tengah pandemi Covid-19 ini diharapkan pelayanan imunisasi harus tetap berjalan dengan baik dengan mengikuti protokol kesehatan agar kegiatan tersebut tetap aman dilaksanakan baik bagi bayi, balita, pendamping bayi balita, kader, maupun petugas kesehatan (Juneris A, dkk, 2020). Kecemasan orang tua di masa pandemi Covid-19 ini bisa jadi disebabkan ketidaktahuan orang tua dalam pencegahan Covid-19 terutama pada saat mengikuti kegiatan posyandu. Alasan lain adalah tidak adanya petunjuk teknis Posyandu yang tersedia pada masa pandemi Covid-19. Kecemasan ini dipengaruhi oleh ancaman Covid-19 terhadap kehidupan ibu dan bayi, serta kekhawatiran tentang tidak terpenuhinya kebutuhan perawatan prenatal, ketegangan hubungan, dan isolasi sosial karena pandemi Covid19 (Lebel et al, 2020). Kecemasan yang berkepanjangan akan menyebabkan stress sehingga mengganggu aktivitas sehari-hari dan menimbulkan ketidakstabilan situasi dan kondisi salah satunya masyarakat takut untuk memeriksakan diri ke pelayanan kesehatan. 


\section{Metodologi}

Pada bab ini dibahas strategi dalam mencari jurnal yang digunakan dalam literature review, pertanyaan yang digunakan untuk melakukan review jurnal yang disesuaikan dengan PICOT dan istilah pencarian jurnal melalui MESH (Medical Subject Heading), batasan mengambil jurnal dan hal lainnya. Mengenai pemilihan bahasa tidak dilakukan karena semua jurnal yang ditemukan telah menggunakan Bahasa Indonesia. Setiap pertanyaan tersebut telah mengikuti PICOT dimana setiap pertanyaan terdapat $\mathrm{P}=$ problem/pasien/populasi, $\mathrm{I}=$ implementasi/intervensi, $\mathrm{C}=$ kontrol/intervensi pembanding, $\mathrm{O}=$ hasil dan $\mathrm{T}=$ Time. Hal lain yang relevan yang penulis gunakan dalam mendapatkan jurnal tentang tingkat kecemasan dan kepatuhan kunjungan Posyandu di masa pandemi Covid-19. Penulis mengambil semua desain penelitian yang digunakan dalam mengidentifikasi tingkat kecemasan dan kepatuhan kunjungan Posyandu di masa pandemi Covid-19.

\section{Hasil \\ 1) Penekanan masalah yang diangkat untuk penelitian}

Penelitian yang dilakukan oleh Junaeris A, dkk (2020) menekankan pada kecemasan pandemi Covid-19 dalam keikutsertaan Posyandu. Tema penelitian ini dibahas secara lebih detail pada penelitian yang dilakukan oleh Auliya M, dkk (2020), pada penelitian tersebut penulis juga mengikutsertakan faktor dukungan keluarga yang mempengaruhi tingkat kecemasan orang tua serta dampaknya dalam kepatuhan imunisasi dasar. Sementara itu penelitian Andi M, dkk (2021) menekankan mengenai evaluasi kunjungan balita di masa pandemi. Ellyzabeth S dan Norif D (2020) menekankan mengenai peran serta kader dalam kegiatan Posyandu balita dengan jumlah kunjungan balita pada era new normal. Penelitian yang dilakukan Ellyzabeth $\mathrm{S}$ dan Norif D (2020) ini mengusung tema yang menyerupai penelitian oleh Andi M, dkk (2021) hanya saja pada penelitian ini penulis lebih fokus ke peran serta kader dan jumlah kunjungan balita di Posyandu. Amalia K, dkk (2020) menekankan pada gambaran kecemasan masyarakat dalam berkunjung ke pelayanan kesehatan pada masa pandemi. Berbeda dengan penelitian sebelumnya yang hanya terfokus pada Posyandu, penelitian yang dilakukan Amalia K, dkk (2020) ini memiliki cakupan yang lebih luas yakni fasilitas kesehatan. Reni P dan Uji U (2020) menekankan pada analisis tingkat kecemasan dengan kepatuhan kunjungan Posyandu di masa Posyandu.

\section{Langkah penelitian atau metode penelitian yang digunakan}

Junaeris A, dkk (2020), Andi M, dkk (2021), Amalia K, dkk (2020) menggunakan metode penelitian deskriptif dan mengumpulkan data dengan menggunakan kuisioner, data yang diperoleh akan dianalisa secara univariat. Junaeris A, dkk (2020) menggunakan metode total sampling dalam pengambilan sampel. Metode penelitian tersebut juga digunakan oleh Auliya M, dkk (2020), hanya saja pada penelitian ini peneliti menyajikan data dalam bentuk distribusi frekuensi karena menggunakan skala kategorik. Sementara itu, Ellyzabeth S dan Norif D (2020) menggunakan metode penelitian kualitatif dan melakukan pengambilan informasi melalui wawancara mendalam (indepth interview) yaitu dengan pertanyaan pertanyaan terbuka. Reni $\mathrm{P}$ dan Uji U (2020) menggunakan metode penelitian kuantitatif dengan 101 (R. Roro Retno Ayu Ericha, et al, 2021) 
pendekatan cross sectional yaitu melakukan pengukuran variabel dependent dan independent serta menggunakan rancangan penelitian observasional analitik. Reni P dan Uji U (2020) menggunakan proses analisis data melalui analisis univariat dan bivariat.

\section{Pembahasan}

\section{Analisis terhadap persamaan dan perbedaan dari setiap penelitian}

Hasil penelitian terhadap 272 responden di ketahui bahwa $89 \%$ masyarakat merasa cemas untuk datang ke pelayanan kesehatan (Amalia K, dkk, 2020). Penelitian menunjukkan bahwa perempuan lebih banyak mengalami kecemasan dari pada laki- laki (Amalia K, dkk, 2020). Kecemasan yang muncul dapat disebabkan karena adanya berbagai perubahan akibat Covid-19, masyarakat diharapkan dapat segera beradaptasi di masa pandemi (Junaeris A, dkk, 2020). Mayoritas tingginya kecemasan yang ditemukan di lokasi penelitian dapat disebabkan oleh mayoritas responden berpengetahuan yang kurang tentang upaya pencegahan infeksi Covid-19 pada saat pelaksanaan Posyandu (Junaeris A, dkk, 2020). Dari hasil penelitian yang dilakukan oleh Junaeris A, dkk (2020) terdapat 49 dari 63 responden (78\%) memiliki kecemasan yang tinggi jika membawa bayi balitanya ke posyandu.

Hasil penelitian yang dilakukan oleh Junaeris A, dkk (2020) ini memiliki kesamaan dengan penelitian Andi M, dkk (2021) dan Amalia K, dkk (2020). Namun, hal ini bertentangan dengan penelitian yang dilakukan oleh Auliya M, dkk (2020) dan Amalia K, dkk (2020). Pada penelitian yang dilakukan oleh Reni P dan Uji U (2020) didapatkan bahwa mayoritas responden $(38,2 \%)$ mengalami kecemasan ringan. Sementara itu, pada penelitian yang dilakukan Auliya M, dkk, 2020 terdapat 2 dari 77 responden $(2,6 \%)$ mengalami kecemasan berat, 40 dari 77 responden $(51,9 \%), 30$ dari

77 responden (39\%) mengalami kecemasan ringan, 5 dari 77 responden $(6,5 \%)$ tidak mengalami kecemasan. Dimana hal ini berarti mayoritas orang tua mengalami kecemasan sedang. Penelitian Auliya M, dkk (2020) juga menambahkan aspek dukungan keluarga dan pengaruhnya dalam kepatuhan imunisasi dasar di masa pandemi, dimana terdapat $58,4 \%$ keluarga mendukung dan $41,6 \%$ tidak mendukung serta terdapat $45,5 \%$ keluarga yang patuh terhadap imunisasi dasar dan $54,5 \%$ keluarga yang tidak patuh.

Mengenai aspek kepatuhan pada penelitian Auliya M, dkk (2020) memiliki hasil yang berbeda dengan penelitian yang dilakukan oleh Reni P dan Uji U (2020). Pada hasil penelitian Reni $\mathrm{P}$ dan $\mathrm{Uji} \mathrm{U}$ (2020) didapatkan sebanyak 60\% responden yang patuh dan terdapat $40 \%$ yang tidak patuh. Sehingga didapatkan kesimpulan bahwa mayoritas responden patuh terhadap kunjungan ke Posyandu. Hasil penelitian menunjukkan jumlah kunjungan balita di Posyandu memiliki kecenderungan selalu berada di bawah target (Ellyzabeth $S$ dan Norif D, 2021). Penelitian menunjukkan bahwa faktor resiko infeksi Covid-19 dipengaruhi oleh usia. Usia dewasa merupakan populasi yang rentan terjadinya penyakit yang dipengaruhi oleh banyak hal antara lain faktor biologi, fisik dan gaya hidup (Amalia K, dkk, 2020). 


\section{Analisis terhadap persamaan dan perbedaan dari setiap penelitian}

Hasil penelitian terhadap 272 responden di ketahui bahwa $89 \%$ masyarakat merasa cemas untuk datang ke pelayanan kesehatan (Amalia K, dkk, 2020). Penelitian menunjukkan bahwa perempuan lebih banyak mengalami kecemasan dari pada laki- laki (Amalia K, dkk, 2020). Kecemasan yang muncul dapat disebabkan karena adanya berbagai perubahan akibat Covid-19, masyarakat diharapkan dapat segera beradaptasi di masa pandemi (Junaeris A, dkk, 2020). Mayoritas tingginya kecemasan yang ditemukan di lokasi penelitian dapat disebabkan oleh mayoritas responden berpengetahuan yang kurang tentang upaya pencegahan infeksi Covid-19 pada saat pelaksanaan Posyandu (Junaeris A, dkk, 2020). Dari hasil penelitian yang dilakukan oleh Junaeris A, dkk (2020) terdapat 49 dari 63 responden (78\%) memiliki kecemasan yang tinggi jika membawa bayi balitanya ke posyandu.

Hasil penelitian yang dilakukan oleh Junaeris A, dkk (2020) ini memiliki kesamaan dengan penelitian Andi M, dkk (2021) dan Amalia K, dkk (2020). Namun, hal ini bertentangan dengan penelitian yang dilakukan oleh Auliya M, dkk (2020) dan Amalia K, dkk (2020). Pada penelitian yang dilakukan oleh Reni P dan Uji U (2020) didapatkan bahwa mayoritas responden (38,2\%) mengalami kecemasan ringan. Sementara itu, pada penelitian yang dilakukan Auliya M, dkk, 2020 terdapat 2 dari 77 responden $(2,6 \%)$ mengalami kecemasan berat, 40 dari 77 responden $(51,9 \%), 30$ dari

77 responden (39\%) mengalami kecemasan ringan, 5 dari 77 responden $(6,5 \%)$ tidak mengalami kecemasan. Dimana hal ini berarti mayoritas orang tua mengalami kecemasan sedang. Penelitian Auliya M, dkk (2020) juga menambahkan aspek dukungan keluarga dan pengaruhnya dalam kepatuhan imunisasi dasar di masa pandemi, dimana terdapat $58,4 \%$ keluarga mendukung dan $41,6 \%$ tidak mendukung serta terdapat $45,5 \%$ keluarga yang patuh terhadap imunisasi dasar dan $54,5 \%$ keluarga yang tidak patuh.

Mengenai aspek kepatuhan pada penelitian Auliya M, dkk (2020) memiliki hasil yang berbeda dengan penelitian yang dilakukan oleh Reni P dan Uji U (2020). Pada hasil penelitian Reni $\mathrm{P}$ dan Uji U (2020) didapatkan sebanyak $60 \%$ responden yang patuh dan terdapat $40 \%$ yang tidak patuh. Sehingga didapatkan kesimpulan bahwa mayoritas responden patuh terhadap kunjungan ke Posyandu. Hasil penelitian menunjukkan jumlah kunjungan balita di Posyandu memiliki kecenderungan selalu berada di bawah target (Ellyzabeth $S$ dan Norif D, 2021). Penelitian menunjukkan bahwa faktor resiko infeksi Covid-19 dipengaruhi oleh usia. Usia dewasa merupakan populasi yang rentan terjadinya penyakit yang dipengaruhi oleh banyak hal antara lain faktor biologi, fisik dan gaya hidup (Amalia K, dkk, 2020). 


\section{Analisis berbagai aspek dari setiap jurnal dengan menggunakan tabel}

\begin{tabular}{|c|l|l|l|l|l|l|}
\hline No & Penulis & \multicolumn{1}{|c|}{ Judul } & Desain & Responden & $\begin{array}{l}\text { Prosedur } \\
\text { Penilaian }\end{array}$ & \multicolumn{1}{|c|}{ Hasil } \\
\hline 1 & $\begin{array}{l}\text { Junaeris } \\
\text { A, dkk } \\
(2020)\end{array}$ & $\begin{array}{l}\text { Kecemasan } \\
\text { Pandemi } \\
\text { Covid-19 } \\
\text { Dalam } \\
\text { Keikutserta } \\
\text { an } \\
\text { Posyandu di } \\
\text { Kelurahan } \\
\text { Pekan } \\
\text { Tanjung } \\
\text { Morawa } \\
\text { Tahun 2020 }\end{array}$ & $\begin{array}{l}\text { Penelitian } \\
\text { Deskriptif }\end{array}$ & $\begin{array}{l}\text { 63 } \\
\text { responden } \\
\text { ibu yang } \\
\text { memiliki } \\
\text { bayi-balita. }\end{array}$ & $\begin{array}{l}\text { Laporan } \\
\text { individu } \\
\text { sendiri } \\
\text { yang } \\
\text { tertuang } \\
\text { dalam } \\
\text { kuisioner. }\end{array}$ & $\begin{array}{l}\text { Dari hasil } \\
\text { penelitian } \\
\text { didapati } \\
\text { bahwa } \\
\text { mayoritas ibu } \\
\text { mengalami } \\
\text { kecemasan } \\
\text { yang } \\
\text { tinggi (78\%). } \\
\text { Kecemasan } \\
\text { muncul dapat } \\
\text { disebabkan } \\
\text { adanya } \\
\text { berbagai } \\
\text { perubahan } \\
\text { akibat Covid- } \\
\text { 19. }\end{array}$ \\
\hline
\end{tabular}




\begin{tabular}{|c|c|c|c|c|c|c|}
\hline 2 & $\begin{array}{l}\text { Auliya } \\
\text { M, dkk } \\
(2020)\end{array}$ & $\begin{array}{l}\text { Dukungan } \\
\text { Keluarga } \\
\text { dan Tingkat } \\
\text { Kecemasan } \\
\text { Orangtua } \\
\text { Dalam } \\
\text { Kepatuhan } \\
\text { Imunisasi } \\
\text { Dasar Pada } \\
\text { Masa } \\
\text { Pandemi } \\
\text { Covid-19 }\end{array}$ & $\begin{array}{l}\text { Deskriptif } \\
\text { Analitik }\end{array}$ & $\begin{array}{l}77 \text { ibu yang } \\
\text { memiliki } \\
\text { bayi yang } \\
\text { berumur 0- } \\
12 \text { bulan } \\
\text { yang ada di } \\
\text { wilayah } \\
\text { kerja } \\
\text { Puskesmas } \\
\text { Nanggalo } \\
\text { Padang. }\end{array}$ & $\begin{array}{l}\text { Responden } \\
\text { mengakses } \\
\text { kuisioner } \\
\text { online. }\end{array}$ & $\begin{array}{l}\text { Didapatkan } \\
45(58.4 \%) \\
\text { responden } \\
\text { memiliki } \\
\text { dukungan } \\
\text { keluarga dan } \\
32 \text { (41.6\%) } \\
\text { responden } \\
\text { tidak } \\
\text { memiliki } \\
\text { dukungan } \\
\text { keluarga, } 5 \\
(6.5 \%) \\
\text { responden } \\
\text { tidak cemas, } \\
30(39.0 \%) \\
\text { responden } \\
\text { memiliki } \\
\text { kecemasan } \\
\text { sedang, } 40 \\
(51.9 \%) \\
\text { responden } \\
\text { memiliki } \\
\text { kecemasan } \\
\text { sedang dan } 2 \\
(2.6 \%) \\
\text { responden } \\
\text { memiliki } \\
\text { kecemasan } \\
\text { berat, } 35 \\
\text { (45.5\%) } \\
\text { responden } \\
\text { patuh } \\
\text { terhadap } \\
\text { pemberian } \\
\text { imunisasi } \\
\text { dasar pada } \\
\text { anak dan } 42 \\
\text { (54.5\%) } \\
\text { responden } \\
\text { tidak patuh } \\
\text { terhadap } \\
\text { pemberian } \\
\text { imunisasi } \\
\text { dasar pada } \\
\text { anak selama } \\
\text { masa pandemi } \\
\text { Covid-19. } \\
\text { }\end{array}$ \\
\hline 3 & $\begin{array}{l}\text { Andi M, } \\
\text { dkk }\end{array}$ & $\begin{array}{l}\text { Evaluasi } \\
\text { Kunjungan }\end{array}$ & $\begin{array}{l}\text { Kuasi } \\
\text { Kualitatif }\end{array}$ & $\begin{array}{l}10 \\
\text { responden }\end{array}$ & $\begin{array}{l}\text { Analisis } \\
\text { informasi }\end{array}$ & $\begin{array}{l}\text { Warga } \\
\text { masyarakat }\end{array}$ \\
\hline
\end{tabular}




\begin{tabular}{|c|c|c|c|c|c|c|}
\hline & (2021) & $\begin{array}{l}\text { Blita ke } \\
\text { Posyandu di } \\
\text { Masa } \\
\text { Pandemi } \\
\text { Covid-19 di } \\
\text { Puskesmas } \\
\text { Totikum } \\
\text { Kab. } \\
\text { Bnggai } \\
\text { Kepulauan }\end{array}$ & & & $\begin{array}{l}\text { dan data } \\
\text { yang } \\
\text { didapat } \\
\text { melalui } \\
\text { catatan } \\
\text { yang } \\
\text { diperoleh } \\
\text { dari } \\
\text { lapangan } \\
\text { dan } \\
\text { rekaman } \\
\text { hasil } \\
\text { wawancar } \\
\text { a } \\
\text { mendalam. }\end{array}$ & $\begin{array}{l}\text { totikum } \\
\text { terkhusus ibu } \\
\text { balita yang } \\
\text { merupakan } \\
\text { salah satu } \\
\text { pengunjung } \\
\text { posyandu, } \\
\text { sangat } \\
\text { merasa } \\
\text { ketakutan } \\
\text { terkait } \\
\text { penyebaran } \\
\text { virus } \\
\text { Corona, } \\
\text { pencatatan } \\
\text { dan pelaporan } \\
\text { selama } \\
\text { Covid tidak } \\
\text { lagi } \\
\text { dilakukan, } \\
\text { sistem } \\
\text { rujukan sudah } \\
\text { berjalan } \\
\text { dengan baik, } \\
\text { dengan } \\
\text { adanya tim } \\
\text { satuan } \\
\text { penanggulang } \\
\text { an Covid-19. }\end{array}$ \\
\hline 4 & $\begin{array}{l}\text { Ellyzabe } \\
\text { th S dan } \\
\text { Norif D } \\
(2021)\end{array}$ & $\begin{array}{l}\text { Peran Serta } \\
\text { Kader } \\
\text { Dalam } \\
\text { Kegiatan } \\
\text { Posyandu } \\
\text { Balita } \\
\text { Dengan } \\
\text { Jumlah } \\
\text { Kunjungan } \\
\text { Balita Pada } \\
\text { Era New } \\
\text { Normal }\end{array}$ & $\begin{array}{l}\text { Penilaian } \\
\text { Kualitatif }\end{array}$ & $\begin{array}{l}8 \text { orang } \\
\text { kader } \\
\text { posyandu } \\
\text { sebagai } \\
\text { informan } \\
\text { utama, } 1 \\
\text { bidan desa } \\
\text { dan } 4 \text { orang } \\
\text { ibu dari } \\
\text { balita } \\
\text { sebagai } \\
\text { informan } \\
\text { triagulasi. }\end{array}$ & $\begin{array}{l}\text { Analisis } \\
\text { informasi } \\
\text { melalui } \\
\text { wawancar } \\
\text { a } \\
\text { mendalam } \\
\text { (indepth } \\
\text { interview) } \\
\text { yaitu } \\
\text { dengan } \\
\text { pertanyaan } \\
\text { pertanyaan } \\
\text { terbuka. }\end{array}$ & $\begin{array}{l}\text { Hasil } \\
\text { penelitian } \\
\text { menunjukan } \\
\text { Jumlah } \\
\text { kunjungan } \\
\text { balita di } \\
\text { Posyandu } \\
\text { pada Era New } \\
\text { Normal selalu } \\
\text { berada di } \\
\text { bawah target, } \\
\text { walau } \\
\text { jumlahnya } \\
\text { sempat } \\
\text { mengalami } \\
\text { kenaikan } \\
\text { namun tetap } \\
\text { berada di } \\
\text { bawah target } \\
\text { selain itu } \\
\text { kader }\end{array}$ \\
\hline
\end{tabular}




\begin{tabular}{|c|c|c|c|c|c|c|}
\hline & & & & & & $\begin{array}{l}\text { memiliki } \\
\text { peran penting } \\
\text { dalam hal ini } \\
\text { karena jika } \\
\text { tidak ada } \\
\text { kader } \\
\text { posyandu } \\
\text { tidak mungkin } \\
\text { ibu balita } \\
\text { mengetahui } \\
\text { operasional } \\
\text { posyandu } \\
\text { di masa } \\
\text { wabah Covid } \\
\text { 19. Namun } \\
\text { keputusan } \\
\text { balita untuk } \\
\text { datang ke } \\
\text { posyandu } \\
\text { balita } \\
\text { pada Era New } \\
\text { Normal } \\
\text { kembali } \\
\text { bergantung } \\
\text { dari ibu balita. }\end{array}$ \\
\hline 5 & $\begin{array}{l}\text { Amalia } \\
\mathrm{K}, \mathrm{dkk} \\
(2020)\end{array}$ & $\begin{array}{l}\text { Gambaran } \\
\text { Kecemasan } \\
\text { Dalam } \\
\text { Berkunjung } \\
\text { ke } \\
\text { Pelayanan } \\
\text { Kesehatan } \\
\text { Pada Masa } \\
\text { Pandemi } \\
\text { Covid-19 }\end{array}$ & $\begin{array}{l}\text { Deskriptif } \\
\text { Survey }\end{array}$ & $\begin{array}{l}272 \\
\text { responden }\end{array}$ & $\begin{array}{l}\text { Responden } \\
\text { mengisi } \\
\text { kuesioner } \\
\text { secara } \\
\text { daring } \\
\text { melalui } \\
\text { google } \\
\text { form. Data } \\
\text { tersebut } \\
\text { kemudian } \\
\text { dianalisis } \\
\text { secara } \\
\text { univariat } \\
\text { mengguna } \\
\text { kan } \\
\text { distribusi } \\
\text { frekuensi. }\end{array}$ & $\begin{array}{l}\text { Hasil } \\
\text { penelitian } \\
\text { menunjukkan } \\
\text { bahwa } \\
\text { perempuan } \\
\text { lebih banyak } \\
\text { mengalami } \\
\text { kecemasan } \\
\text { dibanding laki } \\
\text { laki, 89\% } \\
\text { masyarakat } \\
\text { merasa cemas } \\
\text { untuk datang } \\
\text { ke pelayanan } \\
\text { kesehatan, } \\
59,6 \% \\
\text { mengalami } \\
\text { kecemasan } \\
\text { berat saat } \\
\text { berkunjung ke } \\
\text { posyandu, dan } \\
\text { seluruh } \\
\text { responden } \\
\text { merasa } \\
\text { khawatir }\end{array}$ \\
\hline
\end{tabular}




\begin{tabular}{|c|c|c|c|c|c|c|}
\hline & & & & & & $\begin{array}{l}\text { tertular } \\
\text { COVID-19 } \\
\text { jika } \\
\text { berkunjung ke } \\
\text { pelayanan } \\
\text { kesehatan. }\end{array}$ \\
\hline 6 & $\begin{array}{l}\text { Reni P } \\
\text { dan Uji } \\
\text { U (2020) }\end{array}$ & $\begin{array}{l}\text { Studi } \\
\text { Analisis } \\
\text { Tigkat } \\
\text { Kecemasan } \\
\text { Dengan } \\
\text { Kepatuhan } \\
\text { Kunjungan } \\
\text { Posyandu di } \\
\text { Masa } \\
\text { Pandemi } \\
\text { Covid-19 }\end{array}$ & $\begin{array}{l}\text { Kuantitati } \\
\text { f dengan } \\
\text { pendekata } \\
\text { n cross } \\
\text { sectional }\end{array}$ & $\begin{array}{l}105 \text { ibu } \\
\text { yang } \\
\text { mempunyai } \\
\text { balita dan } \\
\text { datang ke } \\
\text { Posyandu. }\end{array}$ & $\begin{array}{l}\text { Analisis } \\
\text { bivariat } \\
\text { dilakukan } \\
\text { pada dua } \\
\text { variabel } \\
\text { yang } \\
\text { diduga } \\
\text { berhubung } \\
\text { an yaitu } \\
\text { variabel } \\
\text { tingkat } \\
\text { kecemasan } \\
\text { dan } \\
\text { variabel } \\
\text { kepatuhan } \\
\text { kunjungan } \\
\text { posyandu } \\
\text { yang mana } \\
\text { semuanya } \\
\text { diukur } \\
\text { dengan } \\
\text { mengguna } \\
\text { kan uji chi } \\
\text { square } \\
\text { dengan } \\
\text { derajat } \\
\text { kepercaya } \\
\text { an (CI) } \\
95 \% \text { dan } \\
\text { tingkat } \\
\text { signifikan } \\
\alpha=0,05 \text {. }\end{array}$ & $\begin{array}{l}\text { Mayoritas } \\
\text { responden } \\
\text { patuh } \\
\text { terhadap } \\
\text { kunjungan } \\
\text { balita ke } \\
\text { Posyandu } \\
\text { selama masa } \\
\text { pandemi } \\
\text { Covid-19 dan } \\
\text { mayoritas } \\
\text { responden } \\
\text { (38\%) } \\
\text { mengalami } \\
\text { kecemasan } \\
\text { ringan. } \\
\text { Sementara itu, } \\
\text { dari tabel } \\
\text { silang antara } \\
\text { kecemasan } \\
\text { dan kepatuhan } \\
\text { kunjungan } \\
\text { posyandu, } \\
\text { sebagian } \\
\text { responden } \\
\text { mempunyai } \\
\text { kecemasan } \\
\text { ringan dalam } \\
\text { hal Covid-19 } \\
\text { dan mereka } \\
\text { tetap patuh } \\
\text { melakukan } \\
\text { kunjungan } \\
\text { posyandu } \\
\text { selama masa } \\
\text { pandemi dan } \\
\text { dari hasil } \\
\text { analisis } \\
\text { bivariate } \\
\text { dengan uji } \\
\text { Chi Square } \\
\text { didapatkan } \\
\text { bahwa tingkat } \\
\text { kecemasan }\end{array}$ \\
\hline
\end{tabular}




\begin{tabular}{|l|l|l|l|l|l|}
\hline & & & & & $\begin{array}{l}\text { mempengaruh } \\
\text { i kepatuhan } \\
\text { kunjungan } \\
\text { posyandu. }\end{array}$ \\
\hline
\end{tabular}

Simpulan

Dari 6 penelitian yang telah dipaparkan didapatkan bahwa tingkat kecemasan mempengaruhi kepatuhan orang tua dalam melakukan kunjungan balita ke posyandu di masa pandemi Covid-19. Dimana tingkat kecemasan itu sendiri dipengaruhi oleh berbagai hal, antara lain jenis kelamin, pengetahuan responden akan pencegahan Covid dan masih banyak lagi. Berdasarkan penelitian diatas kunjungan balita ke Posyandu selama masa pandemi selalu berada di bawah target, hal ini disebabkan karena adanya rasa ketakutan dan kecemasan orangtua membawa anaknya ke Posyandu. Mayoritas orang tua merasa takut dan cemas akan resiko tertular Covid-19 pada anaknya saat dibawa ke pelayanan kesehatan atau Posyandu.

\section{Daftar Pustaka}

Amrina, Anggi Fina dkk. 2020. Pelaksanaan Kegiatan Posyandu Pada Masa Pandemi Covid-19 Sebagai Upaya Pemenuhan Hak Balita dan Ibu Hamil Sesuai Dengan Rekomendasi Kementrian Kesehatan Republik Indonesia di Desa Bongkok Kramat Kabupaten Tegal. Semarang: Universitas Negeri Semarang.

Multazam, Andi Muhammad dkk. 2021. Evaluasi Kunjungan Balita ke Posyandu di Masa Pandemi Covid-19 di Puskesmas Totikum Kab. Banggai Kepulauan. Journal of Muslim Community Health, 2(3).

Aritonang, Junaeris dkk. 2020. Kecemasan Pandemi Covid-19
Dalam Keikutsertaan Posyandu di Kelurahan Pekan Tanjung Morawa Tahun 2020. Journal Rerproductive Health, 1-6.

Febrina, Rury dan Nadia Sofianis. 2021. Implementasi Program Pemberdayaan Masyarakat Melalui Kegiatan Posyandu Terkait Kesadaran Hidup Sehat Pada Masa Pandemi di Desa Buatan II Kecamatan Koto Gasib. Jurnal Trias Politika, 5(1), 74-81.

Damayanti, Fitriani Nur dan Siti Nurjanah. 2021. Implementasi Posyandu "Balita Sehat" di Masa Pandemi Covid-19. Jurnal Pengabdian Masyarakat Kebidanan, 3(2), 33-38.

Imanah, Norif Didik Nur dan Ellyzabeth Sukmawati. 2021. Peran Serta Kder Dalam Kegiatan Posyandu Balita Dengan Jumlah Kunjungan Balita Pada Era New Normal. Jurnal Kebidanan Indonesia, 12(1), 95-105.

Mardhotillah, Auliya dkk. 2020. Dukungan Keluarga dan Tingkat Kecemasan Orangtua Dalam Kepatuhan Imunisasi Dasar Pada Masa Pandemi Covid-19. Jurnal Keperawatan, 12(4), 1043-1050.

Khoerina, Amalia dkk. 2020. Gambaran Kecemasan Masyarakat Dalam Berkunjung ke Pelayanan Kesehatan Pada Masa Pndemi Covid-19. Jurnal Ilmiah Kesehatan Jiwa, 2(3), 121-128.

Sari, Reni Puspita dan Uji Utami. 2020. Studi Analisis Tingkat Kecemasan Dengan

Kepatuhan Posyandu di Masa Pandemi Covid-19. Jurnal Maternal, 4(2) 